\title{
Depositional ice nucleation on solid ammonium sulfate and glutaric acid particles
}

\author{
K. J. Baustian ${ }^{1,2}$, M. E. Wise ${ }^{1,3}$, and M. A. Tolbert ${ }^{1,3}$ \\ ${ }^{1}$ Cooperative Institute for Research in Environmental Sciences, University of Colorado, Boulder, Colorado, USA \\ ${ }^{2}$ Department of Atmospheric and Oceanic Science, University of Colorado, Boulder, Colorado, USA \\ ${ }^{3}$ Department of Chemistry and Biochemistry, University of Colorado, Boulder, Colorado, USA
}

Received: 1 September 2009 - Published in Atmos. Chem. Phys. Discuss.: 5 October 2009

Revised: 19 January 2010 - Accepted: 29 January 2010 - Published: 5 March 2010

\begin{abstract}
Heterogeneous ice nucleation on solid ammonium sulfate and glutaric acid particles was studied using optical microscopy and Raman spectroscopy. Optical microscopy was used to detect selective nucleation events as water vapor was slowly introduced into an environmental sample cell. Particles that nucleated ice were dried via sublimation and examined in detail using Raman spectroscopy. Depositional ice nucleation is highly selective and occurred preferentially on just a few ammonium sulfate and glutaric acid particles in each sample. For freezing temperatures between $214 \mathrm{~K}$ and $235 \mathrm{~K}$ an average ice saturation ratio of $S=1.10 \pm 0.07$ for solid ammonium sulfate was observed. Over the same temperature range, $\mathrm{S}$ values observed for ice nucleation on glutaric acid particles increased from 1.2 at $235 \mathrm{~K}$ to 1.6 at $218 \mathrm{~K}$. Experiments with externally mixed particles further show that ammonium sulfate is a more potent ice nucleus than glutaric acid. Our results suggest that heterogeneous nucleation on ammonium sulfate may be an important pathway for atmospheric ice nucleation and cirrus cloud formation when solid ammonium sulfate aerosol particles are available for ice formation. This pathway for ice formation may be particularly significant near the tropical tropopause region where sulfates are abundant and other species known to be good ice nuclei are depleted.
\end{abstract}

\section{Introduction}

Atmospheric ice formation is important due to its influence on cloud origination, the global radiation budget, atmospheric chemical reactions, and the global water cycle. For example, cirrus clouds near the tropical tropopause regulate the amount of water vapor that enters the stratosphere. An in-

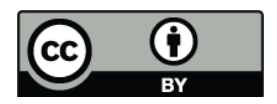

Correspondence to: $\mathrm{M}$. A. Tolbert (margaret.tolbert@ colorado.edu) crease or decrease in the abundance of cirrus clouds formed in this region could significantly impact the amount of water vapor that is transported into the stratosphere. Changes in stratospheric water vapor levels will affect stratospheric chemistry and the formation of polar stratospheric clouds; indirectly affecting ozone loss rates as well (Jensen et al., 1996; Gettelman et al., 2002). The formation of ice clouds and their properties depend strongly on the nucleation mechanism by which they are formed. Although ice formation is a fundamental atmospheric process, the role of individual aerosol particles in ice nucleation remains uncertain. (Cantrell and Heymsfield, 2005; IPCC, 2007)

Ice nucleation has been shown to take place via homogeneous or heterogeneous pathways, as reviewed by Cantrell and Heymsfield (2005). Homogeneous nucleation is observed when aerosol freezing is initiated by an ice crystal that forms within an aqueous aerosol particle. The initial ice crystal catalyzes ice formation and the entire droplet freezes. The role of sulfates in homogeneous ice nucleation has long been investigated due to their hygroscopic nature and ubiquity in the atmosphere. Ice nucleation in aqueous sulfate aerosol particles has been well characterized by numerous different research groups (For examples see, Abbatt et al. (2006), Möhler et al. (2003), Koop et al. (2000), Prenni et al. (2001a) and embedded references). Homogeneous nucleation occurs at temperatures near $235 \mathrm{~K}$ at ice saturation ratios $\left(S_{\text {ice }}=P_{\mathrm{H}_{2} \mathrm{O}} / V P_{\text {ice }}\right)$ between 1.4 and 1.7 .

Heterogeneous nucleation occurs when ice forms on a solid substance, such as an insoluble aerosol particle. For many years, studies of heterogeneous ice nucleation were limited to aerosols with ice-like structures. New evidence shows that other solids may also effectively nucleate ice (Abbatt et al., 2006; Cantrell and Heymsfield, 2005; DeMott et al., 1998; Shilling et al., 2006).

Several recent field and laboratory studies suggest that organic species tend to inhibit atmospheric ice formation. For examples see, Cziczo et al. (2004), DeMott et al. (2003a),

Published by Copernicus Publications on behalf of the European Geosciences Union. 
Möhler et al. (2008), Parsons et al. (2004), Prenni et al. (2001b) and Targino et al. (2006). Other studies have shown that atmospheric species such as minerals, dust and bacteria may encourage ice nucleation to occur at warmer temperatures and lower ice saturation ratios than otherwise observed (Archuleta et al., 2005; DeMott et al., 2003b; Eastwood et al., 2009; Kanji and Abbatt, 2006; Mangold et al., 2005; Möhler et al., 2006; Twohy and Poellot, 2005; Targino et al., 2006). Ice nucleation on particles that are complex mixtures of different species likely depends on the relative surface area of aerosol available for nucleation as well as the chemical properties of individual aerosol types (Abbatt et al., 2006; Kanji and Abbatt, 2006). Although evidence exists that heterogeneous ice nucleation is important to cirrus cloud formation, the mechanism and chemical processes by which it occurs are not well understood and require more investigation.

In the present study we probe heterogeneous ice nucleation using Raman spectroscopy in combination with an environmental cell and an optical microscope. This system allows us to examine ice formation on a particle-by-particle basis. Several experiments have previously been performed using either Raman spectroscopy or optical microscopy to investigate ice nucleation on atmospheric particles. Mund and Zellner (2003) use Raman spectroscopy to investigate homogeneous nucleation of optically levitated sulfuric acid droplets. Koop et al. (1998) make use of optical microscopy to observe ice nucleation from sulfuric acid particles. Buajarern et al. (2007) show that Raman spectroscopy combined with an optical tweezing technique can be effectively used to investigate evaporation rates of surface-active organic compounds. Chan et al. (2006) used Raman spectroscopy and an electro dynamic balance to investigate aerosol hygroscopicity on solid ammonium sulfate particles containing glutaric acid coatings at room temperature. Kanji et al. (2008) investigated depositional nucleation on mineral dust using optical microscopy for ice detection. Knopf and Koop (2006) investigated heterogeneous ice nucleation on single particles of mineral dust using confocal Raman spectroscopy and optical microscopy.

In the present study, onset-freezing conditions for heterogeneous ice nucleation on solid ammonium sulfate and glutaric acid particles are reported. Ammonium sulfate was chosen due to its high concentration in the troposphere. Additionally, several recent studies (Abbatt et al., 2006; Eastwood et al., 2009; Mangold et al., 2005; Shilling et al., 2006) have demonstrated that ice nucleation on solid ammonium sulfate may be an important pathway for atmospheric ice formation. Glutaric acid $\left(\mathrm{HO}_{2} \mathrm{C}\left(\mathrm{CH}_{2}\right)_{3} \mathrm{CO}_{2} \mathrm{H}\right)$ was chosen as a representative organic species because it is a partially soluble dicarboxylic acid and it is commonly found in the atmosphere as a component of secondary organic aerosol.

Specifically, this study investigates onset-freezing conditions for depositional ice nucleation in two types of experiments. Ice formation was first observed on solid ammonium

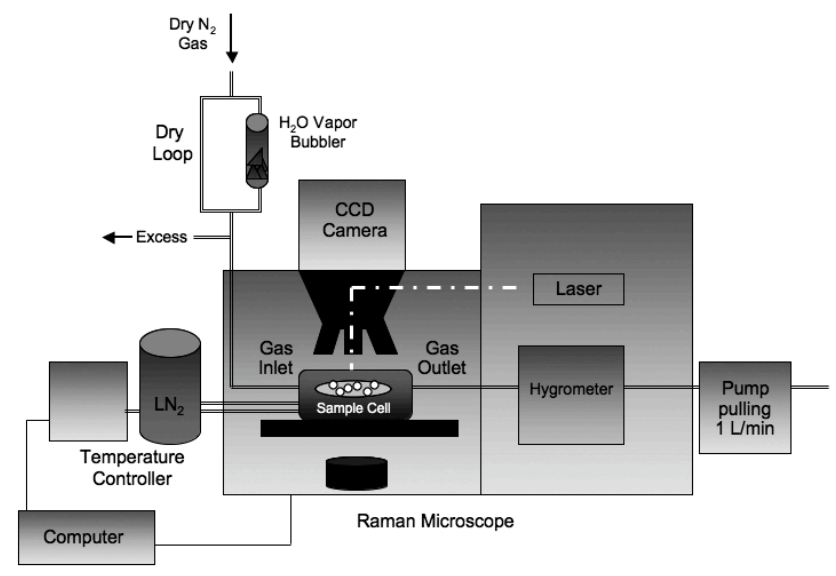

Fig. 1. Experimental setup used for investigating ice nucleation. Particles impacted on a quartz disc are placed in the sample cell prior to experimentation. Humidified air is produced by running dry $\mathrm{N}_{2}$ gas through a glass frit. The humidified air enters the cell through the gas inlet and exits via the gas outlet. Cell temperature is monitored with a platinum resistance sensor and regulated by a temperature controller that is attached to the sample cell. RH is measured by a hygrometer attached to the gas outlet of the sample cell. The sample may be examined visually using the CCD camera that is attached to the optical microscope. A Raman spectrum of the sample may also be obtained using a frequency doubled Nd:YVO DPSS laser operated at $532 \mathrm{~nm}$ or externally stabilized diode laser operated at $780 \mathrm{~nm}$.

sulfate and solid glutaric acid particles independently. Critical ice saturation ratios $\left(S_{\text {ice }}\right)$ calculated at the onset of freezing for each species are reported. In the second type of experiment, ice was depositionally nucleated on solid ammonium sulfate and glutaric acid particles that were externally mixed in the same sample. For each experiment of this type, ice saturation ratios are reported and Raman spectroscopy was used to determine the identity of the ice nucleus responsible for the onset of freezing. Aerosol size and number concentrations were held approximately constant, allowing for a direct comparison of nucleation potential based on the chemical properties of the aerosol particles examined.

\section{Experimental}

\subsection{The Raman system and reaction cell}

A schematic of the experimental system used to probe ice nucleation is shown in Fig. 1. The Raman system consists of a Nicolet Almega XR Dispersive Raman spectrometer that has been outfitted with a Linkam THMS600 environmental cell, a Buck Research chilled-mirror hygrometer and a Linkam automated temperature controller. The Raman spectrometer features an Olympus BX51 research-grade optical microscope with 10X, 20X and 50X magnification capabilities. In addition, the Almega spectrometer has two separate lasers 
$(532 \mathrm{~nm}$ and $780 \mathrm{~nm})$ that can be used to probe samples as small as $1 \mu \mathrm{m}$ in diameter. For each experiment performed in this study the $532 \mathrm{~nm}$ laser was used to gather spectral information. The vibrational spectra obtained are chemically specific and allow for molecular identification on a particleby-particle basis. It is also possible to depth profile or map different regions of single micrometer-sized particles to assess compositional variability.

A Linkam THMS600 cell is mounted on an Almega Prior high precision motorized microscope stage that sits within the microscope compartment. The cell has a working temperature range from $-196^{\circ}$ to $600^{\circ} \mathrm{C}$, which spans the entire atmospheric temperature range. Samples are placed on a silver block that is cooled with a continuous flow of liquid $\mathrm{N}_{2}$. Temperature control is achieved by two counter-heating elements. A platinum resistance sensor mounted within the silver sample block monitors cell temperature accurately to $\pm 0.1^{\circ} \mathrm{C}$. The flow rate of liquid $\mathrm{N}_{2}$ and cell temperature is controlled automatically using the Linkam TMS94 temperature controller. Additionally, the cell has inlets for gases and evacuation that allow for strict control over the sample environment. The cell is operated in a continuous flow manner with a background of purified nitrogen gas that may be humidified as desired.

Humidified air is generated from bursting bubbles created by running purge gas through a glass frit. This wet air is then mixed with dry purge gas in variable ratios to create a humidified flow. Increasing or decreasing airflow through the glass frit controls relative humidity $(\mathrm{RH})$; the flow of dry nitrogen remains constant.

The RH environment of the sample is monitored using a CR-1A chilled-mirror hygrometer (Buck Research Instruments, L.L.C.) attached to the gas outlet of the cell. The CR$1 \mathrm{~A}$ hygrometer measures frost points as low as $-120^{\circ} \mathrm{C}$ with an accuracy of $\pm 0.15^{\circ} \mathrm{C}$. Frost point measurements from the hygrometer and sample temperature (from the platinum resistor sensor) allow for real-time monitoring of RH during experimentation. A Gast Manufacturing diaphragm pump pulling at a rate of $1 \mathrm{~L} / \mathrm{min}$ is attached to the outlet of the hygrometer. The pump ensures the airflow through the cell will always be $1 \mathrm{~L} / \mathrm{min}$, regardless of any variability due to changing the flow rate through the water vapor bubbler.

It is important to note that the liquid $\mathrm{N}_{2}$ supply lines for the commercially available Linkam cryo-stage are located within the sample compartment. If humidified air were introduced into the cell without modification the liquid $\mathrm{N}_{2}$ tubes would act as a water vapor sink. Thus, the authors have taken great care to adequately insulate the liquid $\mathrm{N}_{2}$ lines, ensuring that the silver sample block is the coldest point within the cell. The supply lines have been carefully wrapped in several layers of polystyrene foam and the entire area has been covered in a thick coat of low vapor pressure putty to fill any small cracks in the insulation. To test this insulation system, vapor pressure measurements at the inlet and outlet of the cell were compared at a set temperature and $\mathrm{RH}$ level. If a water va- por sink existed in the cell, such as ice forming on the cold liquid $\mathrm{N}_{2}$ pipes, the vapor pressure at the cell outlet would be lower than at the gas inlet. During this insulation test, the cell was cooled to $223 \mathrm{~K}$ and water vapor was added until the vapor pressure was near ice saturation with respect to the temperature of the silver block. Under these conditions, ice formation would not occur on the silver block, but would form on the much colder liquid nitrogen lines if they were not properly insulated. When the inlet and outlet vapor pressures were compared, there was only a $0.39 \%$ difference between the two vapor pressure measurements.

\subsection{Temperature calibration}

Calculations of RH and $S_{\text {ice }}$ rely on accurate measurements of temperature. Therefore, a temperature calibration was performed to correct for differences between the temperature measured by the platinum resistance sensor embedded in the silver sample block and the temperature of aerosol particles resting on top of the quartz sample substrate. Our calibration was performed by back-calculating temperature based on the observed deliquescence point of $\mathrm{NaCl}$ particles in our cell. For each calibration point a new sample of dry atomized $\mathrm{NaCl}$ particles was placed in the cell and cooled below $0{ }^{\circ} \mathrm{C}$. Water vapor was then introduced into the system slowly until deliquescence was detected using the spectral change in the Raman signature. Deliquescence was additionally confirmed visually using the optical microscope. The frost point at which deliquescence occurred was recorded from the hygrometer and then used to obtain a vapor pressure. Martin (2000) has shown that the deliquescence $\mathrm{RH}$ of $\mathrm{NaCl}$ is $75 \%$ and does not vary with temperature. Therefore, using the vapor pressure obtained experimentally and the known deliquescence point, we were able to back-calculate the actual temperature the particles were experiencing. We performed this calibration at five different temperature settings. When the calculated temperature was plotted verses temperature controller setting, the data was well approximated $\left(R^{2}=0.998\right)$ by a linear fit. A graph of the temperature calibration curve is shown in Fig. 2. This calibration shows the actual temperature a particle experiences is warmer than the temperature controller setting by about $2{ }^{\circ} \mathrm{C}$. This temperature difference is largely due to the addition of room temperature dry $\mathrm{N}_{2}$ to the cold cell during experimentation.

Calibration points using $\mathrm{NaCl}$ were not possible at temperatures below $-40^{\circ} \mathrm{C}$ because depositional ice nucleation would occur prior to deliquescence and monopolize the water vapor supply. However, spectral changes in the ammonium sulfate spectrum were observed when particles were cooled below a calibrated temperature of $222.9 \mathrm{~K}$. This matches the expected para- to ferroelectric phase transition temperature of ammonium sulfate ( $T=223.1 \mathrm{~K}$, Hung et al., 2002; Knopf and Koop, 2006) thus confirming that our temperature calibration could be extended to colder temperatures. Spectral changes at this transition are depicted in Fig. 3. Most 


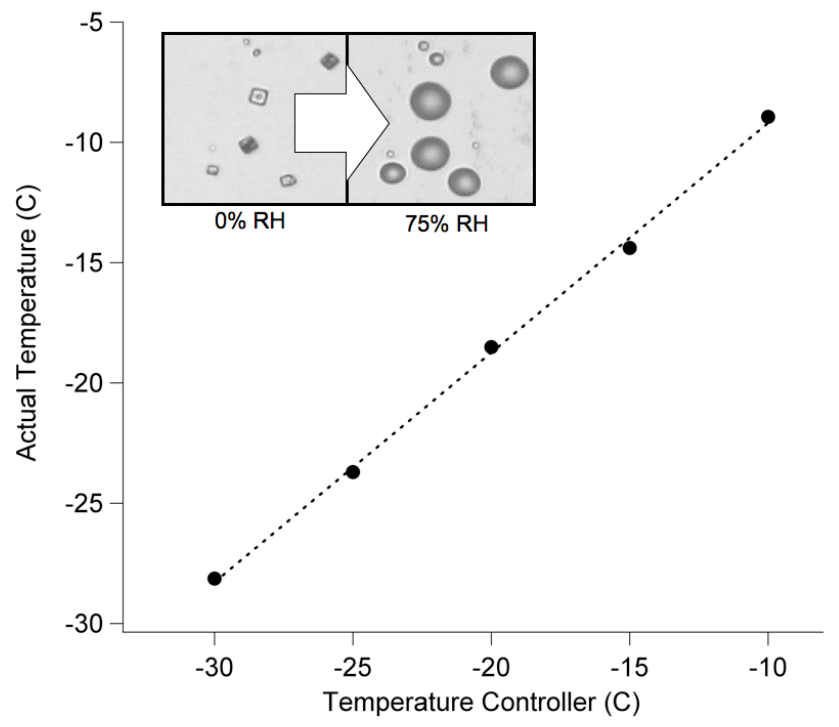

Fig. 2. Temperature calibration curve constructed by calculating actual particle temperature from the observed deliquescence relative humidity of $\mathrm{NaCl}$ particles.

notably, the ammonium peak between $2800-3300 \mathrm{~cm}^{-1}$ becomes asymmetrical due to the development of a peak at $3026 \mathrm{~cm}^{-1}$ (Fig. 3, line A). This transition is additionally marked by the subtle appearance of a shoulder on the ammonium peak between $3000 \mathrm{~cm}^{-1}$ and $3200 \mathrm{~cm}^{-1}$. The sulfate peak $\left(974 \mathrm{~cm}^{-1}, 298 \mathrm{~K}\right)$ also sharpens, intensifies and shifts to $972 \mathrm{~cm}^{-1}$ at temperatures lower than $223.1 \mathrm{~K}$. Intensification and sharpening of these spectral features continues as temperatures are lowered past the ferroelectric transition temperature. To provide the most accurate results possible, the calibrated temperature was used for all calculations presented in this investigation.

\subsection{Particle generation and sample preparation}

Aerosol particles were produced by delivering a $10 \mathrm{wt} \%$ solution of either ammonium sulfate or glutaric acid to an atomizer (TSI 3076) at a rate of $2 \mathrm{ml} / \mathrm{min}$ using a Harvard apparatus syringe pump. Particles were impacted directly onto microscope grade quartz discs (1 mm thick) in a flow of dry $\mathrm{N}_{2}$ at $1.5 \mathrm{~L} / \mathrm{min}$. Prior to experimentation, the quartz discs were cleaned with methanol and then treated with commercially available Rain-X, a hydrophobic silanizing agent (ethanol (1-10\%), isopropanol (75-95\%), polysiloxanes, and organosilanes) to minimize heterogeneous effects of the substrate on ice nucleation. The quartz discs were exposed to the particle flow for 3 seconds. Individual particle diameters range from $0.5-10 \mu \mathrm{m}$ in diameter. The mean particle sizes for ammonium sulfate, glutaric acid and mixed-sample particles are $2.1 \mu \mathrm{m}, 2.4 \mu \mathrm{m}$, and $2.1 \mu \mathrm{m}$ with standard deviations of $1.0 \mu \mathrm{m}, 1.7 \mu \mathrm{m}$, and $1.5 \mu \mathrm{m}$, respectively. Kanji and

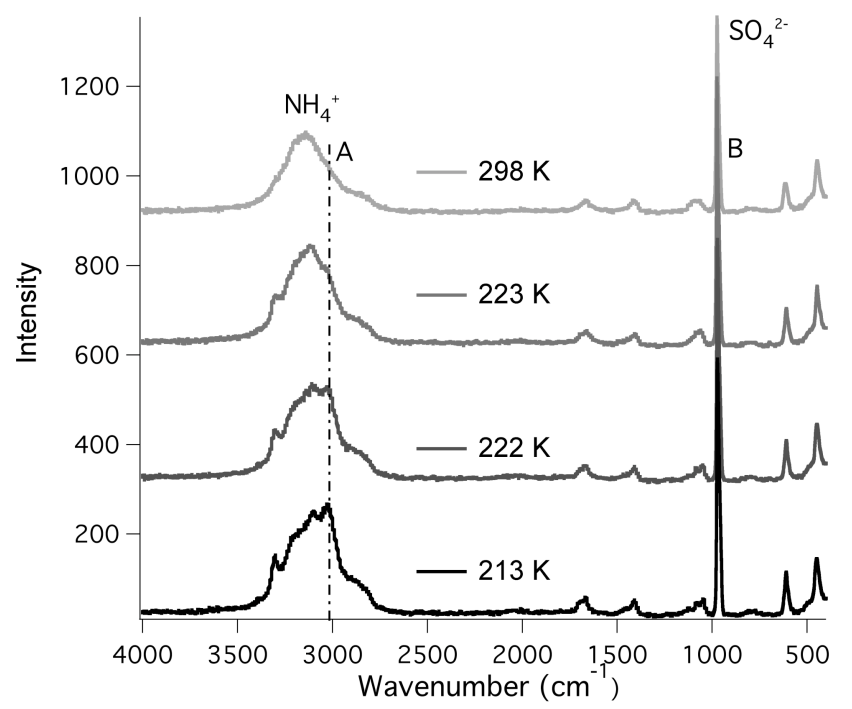

Fig. 3. Vibrational spectra of ammonium sulfate as a function of temperature using Raman spectroscopy. Characteristic vibrational bands for $\mathrm{SO}_{4}^{2-}$ and $\mathrm{NH}^{+}$are indicated at $974 \mathrm{~cm}^{-1}$ and $3143 \mathrm{~cm}^{-1}$, respectively. At colder temperatures Raman modes often sharpen and intensify. In addition to this intensification, distinct changes are observed at the para- to ferroelectric transition temperature $(T=223.1 \mathrm{~K})$ for ammonium sulfate. One change observed at this transition is indicated by line $\mathrm{A}$, which highlights the appearance of a peak at $3026 \mathrm{~cm}^{-1}$ in the $\mathrm{NH}_{4}$ vibrational mode as temperature is decreased. The sulfate peak (B) also shifts from $974 \mathrm{~cm}^{-1}$ to $972 \mathrm{~cm}^{-1}$ at the ferroelectric transition temperature. More detailed discussion of these spectral changes can be found in Torrie et al. (1972).

Abbatt (2006) find that $S_{\text {ice }}$ required for ice nucleation is inversely related to the available aerosol surface area. Thus, every effort has been made to ensure that particle size and number concentration remains consistent on every sample. This sample preparation method results in approximately $10^{3}$ particles in the 10X field of view at any time. Thus, when a single ice particle is detected, this corresponds to an optimal nucleation detection limit of approximately $0.1 \%$ of the particles in view.

To create samples containing externally mixed ammonium sulfate and glutaric acid particles, the sample preparation process was slightly modified. First, a sample of pure glutaric acid particles was generated using the same conditions as described above. The sample containing only glutaric acid particles was then placed in the cell to dry in a flow of purified $\mathrm{N}_{2}$ for $30 \mathrm{~min}$ at a dew point of around $213 \mathrm{~K}$ and a temperature of $236 \mathrm{~K}$. After the allotted drying time, ammonium sulfate particles were atomized onto the sample containing the dry glutaric acid aerosol particles. This process yielded samples containing an external mixture of ammonium sulfate and glutaric acid particles. Each mixed sample was screened using Raman spectroscopy prior to 
experimentation to ensure the presence of pure ammonium sulfate and pure glutaric acid particles. In some cases, internally mixed particles consisting of an ammonium sulfate core and a small amount of glutaric acid were observed. The authors speculate that these internally mixed particles resulted on occasion from the impact of an ammonium sulfate particle with a glutaric acid particle during sample generation.

\subsection{Depositional ice nucleation experiments}

Once a sample had been placed in the cell, a typical depositional ice experiment began by running $\mathrm{N}_{2}$ gas through the cell at $1 \mathrm{~L} / \mathrm{min}(298 \mathrm{~K})$ until the system dried and settled to a baseline dew point between $223 \mathrm{~K}$ and $203 \mathrm{~K}$. The cell was then cooled to the temperature desired for the experiment $(214-233 \mathrm{~K})$ and allowed to rest for several minutes to ensure temperature stabilization. Water vapor was slowly introduced into the system by systematically increasing the ratio of humidified air to $\mathrm{N}_{2}$ gas that entered the cell. Water vapor was added in a stepwise fashion. Meanwhile, the particles were monitored visually at $10 \mathrm{X}$ magnification using the video output from the CCD camera mounted on the spectrometer. The onset of ice nucleation was denoted by the first ice particle that was observed. It was typically quite easy to identify particles on which nucleation occurred because they quickly grew to large sizes compared to surrounding particles that remained dry. The vapor pressure at the onset of ice nucleation was recorded and the nucleation event was documented with visual imagery. The $50 \mathrm{X}$ objective was then used for closer inspection of the ice crystal and the particle responsible for nucleation. The nucleation event was documented at 50X magnification using both optical microscopy and Raman spectroscopy. Next the supply of water vapor to the cell was cut off and the cell was slowly warmed. This resulted in ice sublimation and exposed the ice nucleus for further investigation. The final step in the experiment was to visually and spectroscopically examine the particle responsible for nucleation.

A single sample was generally used in several ice nucleation experiments. Between each experiment the sample was warmed to $298 \mathrm{~K}$ and dried to a baseline dew point between 223 and $203 \mathrm{~K}$ to ensure that preactivation (Knopf and Koop, 2006; Wallace and Hobbs, 2006 embedded references) did not affect experimental results. It is interesting to note that the same particle was never observed to nucleate ice twice when a sample was used in several consecutive experiments.

Identical experiments were performed on blank quartz substrates to ensure that ice nucleation was not induced by imperfections in the substrate material. Ice nucleation on blank quartz substrates occurred at $S_{\text {ice }}$ values between 1.6 and 2.33 over the temperature range observed.

\subsection{Calculating critical ice saturation ratios}

Critical ice saturation ratio $\left(S_{\text {ice }}\right)$ is a parameter widely used in cloud microphysics and in atmospheric models. It is defined as:

$S_{\text {ice }}(T)=P_{\mathrm{H}_{2} 0} / V P_{\text {ice }}(T)$

where $P_{\mathrm{H}_{2} 0}$ is the water partial pressure at the temperature when ice formation is observed and $V P_{\text {ice }}(T)$ is the equilibrium vapor pressure of water over ice at the same temperature. Using the calibrated cell temperature, $V P_{\text {ice }}(T)$ was calculated using equations from Marti and Mauersberger (1993). $P_{\mathrm{H}_{2} 0}$ was calculated from frost points measured using the Buck Research chilled-mirror hygrometer. The hygrometer outputs frost points which are converted to vapor pressures using formulations developed by Buck (1981). In addition to calibrations performed by the manufacturer, the hygrometer was found to accurately measure frost points when tested in our laboratory. During these tests, the hygrometer was attached to a flow tube apparatus containing pure water ice. Frost point measurements were made at the flow tube outlet for 19 different experiments at temperatures between $221 \mathrm{~K}$ and $233 \mathrm{~K}$ as dry $\mathrm{N}_{2}$ flowed at $4 \mathrm{~L} / \mathrm{min}$ through the system. The vapor pressure over pure ice in the flow tube apparatus was measured by the hygrometer and compared to theoretical vapor pressure calculations made using formulations by Marti and Mauersberger (1993). On average, vapor pressure measurements from these experiments were within $0.93 \%$ of the theoretical predictions. In this study, $S_{\text {ice }}$ was calculated for the onset of freezing in each experiment and reported as a function of freezing temperature.

\section{Results}

\subsection{Depositional ice nucleation on ammonium sulfate particles}

Visual imagery obtained during a representative ammonium sulfate experiment are shown in Fig. 4. The first image (A) shows solid ammonium sulfate particles (10X magnification) just after being placed in the sample compartment and before any water vapor had been introduced into the system. During experimentation a motorized stage was used to move around a small region of the sample to look for ice. For the example experiment, the sample was cooled to $218.1 \mathrm{~K}$ and water vapor was slowly added to the system until ice nucleation was observed at a frost point of $218.5 \mathrm{~K}$ (B). The 50X microscope objective was then used for closer inspection of the ice crystal. In this example, the ammonium sulfate ice nucleus can be seen through the ice crystal. A Raman spectrum of the ice crystal and optical image (C) were obtained at this magnification level. Finally, humidified flow to the cell was cut off and the ice sublimed revealing the particle responsible for 


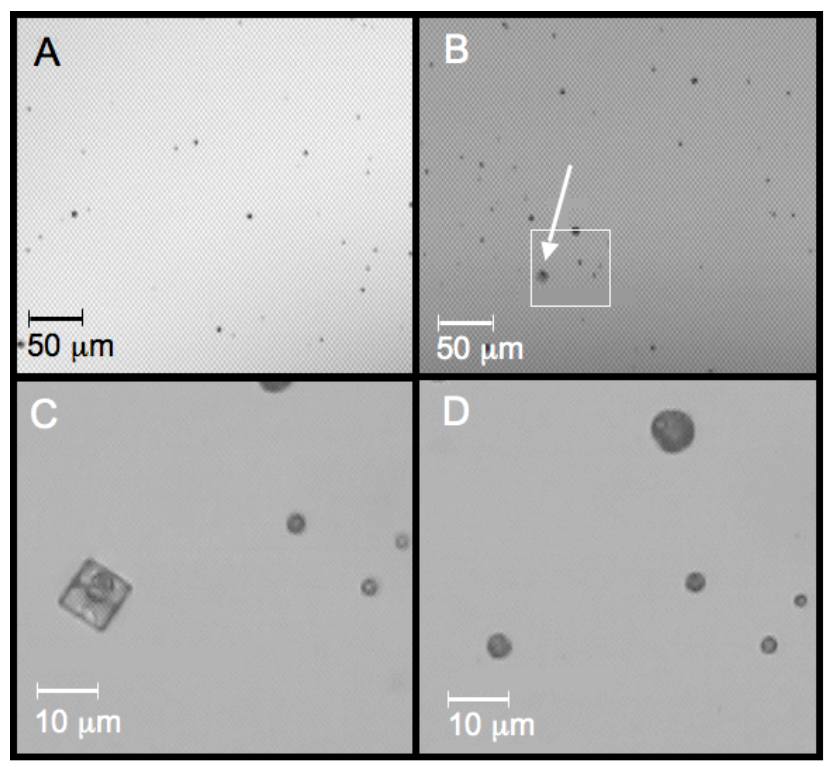

Fig. 4. Images recorded during a depositional ice nucleation experiment on ammonium sulfate. Image (A) (10X magnification) shows a group of dry ammonium sulfate particles prior to experimentation. Image (B) (10X magnification) focuses on the ice crystal that marked the onset of ice formation. Image (C) was taken of the same ice crystal at 50X magnification for closer inspection. The particle in image (D) (50X magnification) is the ice nucleus remaining after the ice has been sublimed.

nucleation (D). In this case the particle revealed is $\sim 5 \mu \mathrm{m}$ in diameter. The frost point at which nucleation was observed corresponds to a critical ice saturation ratio of 1.04 and $\mathrm{RH}$ of $61.6 \%$.

Spectral data obtained during the same ice nucleation experiment are shown in Fig. 5, panel A. The top Raman spectrum was obtained from the ice particle that formed at $218.1 \mathrm{~K}$. The Raman signal for water ice at $3132 \mathrm{~cm}^{-1}$ (peak a) dominates the spectrum but the sharp sulfate peak of ammonium sulfate is still clearly visible around $972 \mathrm{~cm}^{-1}$ (peak c). Another spectrum was obtained by probing the ice nucleus that remained after sublimation of the surrounding ice. A spectrum (Fig. 5, panel A, bottom) of the remaining particle confirms that it is pure ammonium sulfate. The strong sharp sulfate peak at $972 \mathrm{~cm}^{-1}$ (peak c) and the N-H vibrations between $2800-3300 \mathrm{~cm}^{-1}$ (peak b) characterize the Raman spectrum of solid ammonium sulfate.

Twenty-four ammonium sulfate ice nucleation experiments were performed over a range of temperatures (214$233 \mathrm{~K})$. Results obtained for ammonium sulfate are shown as open circles in Fig. 6. Over this temperature range, $S_{\text {ice }}$ values for depositional nucleation on ammonium sulfate varied between 0.96 and 1.29. The average $S_{\text {ice }}$ is 1.10 with a standard deviation of 0.07 . These results indicate that depositional ice nucleation on solid ammonium sulfate does not have a significant temperature dependence over this temper-

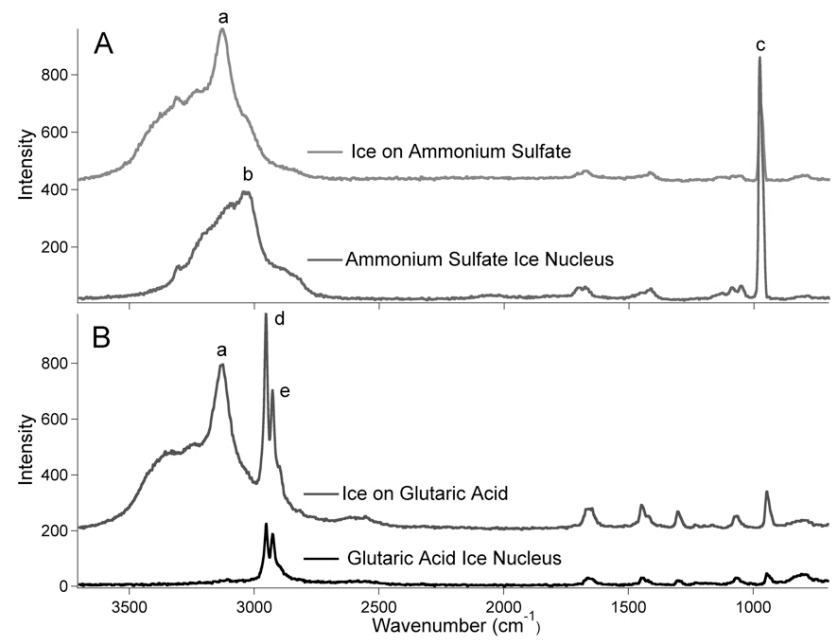

Fig. 5. Panel (A) shows Raman spectra taken during a depositional nucleation experiment on ammonium sulfate. Humidified air was slowly introduced into the sample cell and ice formation was observed (panel A, top spectrum) at $218.1 \mathrm{~K}$. Peak a corresponds to the $v(\mathrm{OH})$ band of water ice at $3132 \mathrm{~cm}^{-1}$ (Whalley, 1977). Although the water ice signal is strong, the sulfate vibrational signature from the ammonium sulfate ice nucleus is clearly visible at $972 \mathrm{~cm}^{-1}$ (marked as c). The ice was sublimed with dry $\mathrm{N}_{2}$ gas and a spectrum (panel A, bottom) was taken of the dry ammonium sulfate particle responsible for nucleation. In this spectrum the $\mathrm{NH}_{4}$ vibrational band between $2800 \mathrm{~cm}^{-1}$ and $3300 \mathrm{~cm}^{-1}$ (peak b) is apparent in addition to the strong sulfate band (peak c). In this example spectral deformation of the $\mathrm{NH}_{4}$ mode is observed because the temperature was below the para-to ferroelectric phase transition temperature of ammonium sulfate $(T=223.1 \mathrm{~K})$. Panel $(\mathbf{B})$ shows spectra obtained during a glutaric acid ice nucleation experiment. The characteristic vibrational modes used to identify glutaric acid are the strong $\mathrm{C}-\mathrm{H}$ stretching bands indicated by $\mathrm{d}$ and e at frequencies $2950 \mathrm{~cm}^{-1}$ and $2925 \mathrm{~cm}^{-1}$, respectively. During this experiment the cell was held at a temperature of $229.8 \mathrm{~K}$ and water was slowly introduced into the system until ice formation was observed (panel B, top spectrum). After ice nucleation, the water vapor source was cut and the ice is sublimed to reveal the particle beneath the ice. A spectrum of the ice nucleus confirmed that it was glutaric acid (panel B, bottom). Like ammonium sulfate, the Raman modes of glutaric acid in these spectra appear intensified and sharpened due to cold temperatures.

ature range. Ice saturation ratios on solid ammonium sulfate are distinctly lower than those expected for homogeneous nucleation as predicted by Koop et al. (2000). The deliquescence RH of ammonium sulfate is approximately $83 \%$ over this temperature range (extrapolated from Onasch et al., 1999). Experimental values of RH, measured at the onset of depositional ice formation on ammonium sulfate, range from $61-78 \%$. In every experiment, ice formation was observed at humidity levels below the deliquescence RH of ammonium sulfate. During every experiment Raman spectroscopy was also used to probe ammonium sulfate particles that did not 


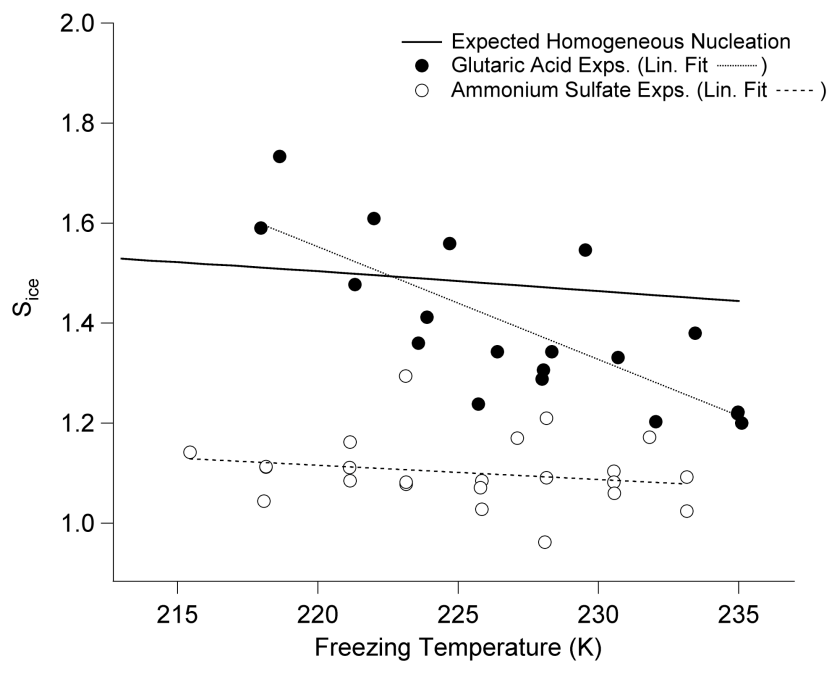

Fig. 6. Ice saturation ratios as a function of freezing temperature for all depositional ice nucleation experiments performed on ammonium sulfate and glutaric acid. Open circles represent ice nucleation experiments on solid ammonium sulfate particles. Dark cir-

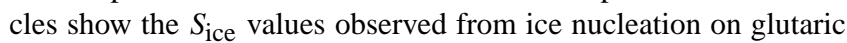
acid particles. Dotted lines represent linear fits to the ammonium sulfate and glutaric acid experimental results. The thick solid line illustrates where homogeneous freezing is expected to take place based on the model developed by Koop et al. (2000).

nucleate ice. Water due to deliquescence was never observed on any particles. Therefore homogeneous nucleation could not have taken place. Visual and spectral observations additionally indicated that homogeneous nucleation did not occur.

\subsection{Depositional ice nucleation on glutaric acid particles}

Spectral data obtained during a representative glutaric acid experiment are shown in Fig. 5, panel B. The top spectrum indicates the presence of ice (peak a, $3132 \mathrm{~cm}^{-1}$ ) along with glutaric acid. The characteristic $\mathrm{C}-\mathrm{H}$ stretching modes at $2950 \mathrm{~cm}^{-1}$ and $2925 \mathrm{~cm}^{-1}$ (peaks d and e) were used to identify glutaric acid. When the ice was sublimed, the particle responsible for ice nucleation was revealed. A spectrum (Fig. 5, panel B, bottom) of this particle confirms that it is glutaric acid.

Glutaric acid is a polymorphic substance, meaning that it can exist in multiple crystalline states. Comparison of spectra presented in this study with those of Yeung et al. (2010) suggest that the solid glutaric acid particles examined in this study were present in the metastable $\alpha$-form.

Nineteen ice nucleation experiments using glutaric acid were performed in this study. The ice saturation ratios observed for each of these experiments are plotted alongside the ammonium sulfate results shown in Fig. 6. Depositional ice nucleation on glutaric acid appears to depend on temperature over this range. $S_{\text {ice }}$ values range from 1.20 to 1.73 with the lowest $S_{\text {ice }}$ values observed at the warmest temperatures. The average $S_{\text {ice }}$ calculated for depositional ice nucleation on glutaric acid is 1.39 with a standard deviation of 0.16 . The results for experiments on glutaric acid intersect the curve for expected homogeneous nucleation (solid line, Fig. 6). However, this curve does not apply until glutaric acid is in solution. Over this temperature range glutaric acid has a deliquescence RH that is around 100\% (inferred from Parsons et al., 2004). Values of RH calculated when ice formation was first observed on glutaric acid range from 77-98\%. As with ammonium sulfate, for all experiments on glutaric acid depositional nucleation was observed at lower levels of RH than necessary for deliquescence to occur. Similarly, water in the particles due to deliquescence was not detected in visual or spectral results. This suggests that homogeneous nucleation could not have occurred. However, at temperatures colder than $225 \mathrm{~K}$ (the intersection point with the homogeneous freezing line), if the deliquescence RH of glutaric acid was exceeded, it is likely that the glutaric acid and water solution would immediately freeze homogeneously. These results suggest that solid glutaric acid is not an efficient heterogeneous ice nucleus and that its nucleation efficiency declines with decreasing temperature.

\subsection{Mixed-sample experiments}

Results obtained from the initial ammonium sulfate and glutaric acid experiments indicated that ammonium sulfate was a more efficient ice nucleus than glutaric acid, especially at colder temperatures. In order to substantiate this hypothesis a third series of experiments were conducted using samples containing both ammonium sulfate and glutaric acid particles.

For these experiments, samples containing external mixtures of ammonium sulfate and glutaric acid were prepared. Raman spectroscopy was used to determine the chemical composition of the particle that initiated ice nucleation in each experiment. Although Raman spectroscopy was used for definitive particle identification, ammonium sulfate and glutaric acid particles are visually distinct as well. In the optical microscope, solid ammonium sulfate particles tend to look darker in color and rougher in texture compared to glutaric acid particles. This distinction is evident in Fig. 7, a 50X optical image taken of particles from a mixed sample prior to experimentation.

Seventeen mixed-sample experiments were conducted at temperatures ranging from $214-224 \mathrm{~K}$. These experiments were performed in the colder half of the temperature range used for previous experimentation because this is where the largest difference in supersaturation level required for the onset of freezing was observed when comparing ammonium sulfate and glutaric acid. Ice saturation ratios obtained at the onset of ice formation for the mixed-sample experiments are shown in Fig. 8 as gray circles. An average ice saturation ratio of 1.13 with a standard deviation of 0.09 was obtained 


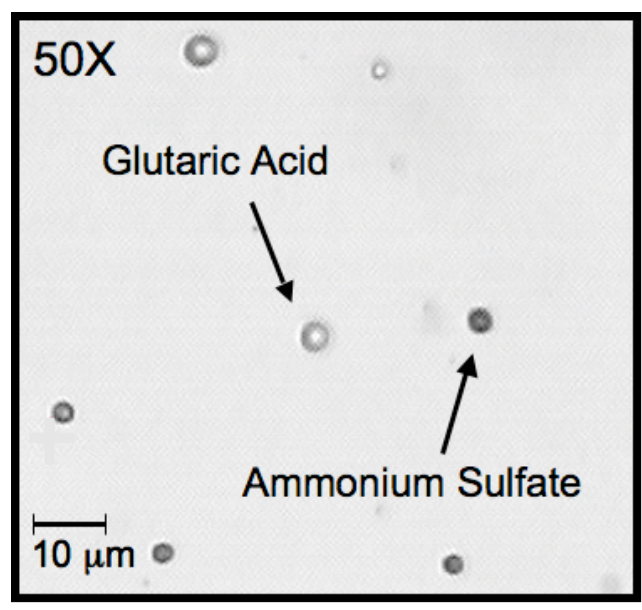

Fig. 7. Image recorded of ammonium sulfate and glutaric acid particles during a mixed-sample experiment. At 50X magnification the dark ammonium sulfate particles are visibly distinct compared to the light gray glutaric acid particles.

for the mixed-sample experiments. Ice saturation ratios calculated for the mixed-sample experiments are similar to the results obtained for samples of pure ammonium sulfate.

Raman spectroscopy was used to establish the identity of the aerosol species responsible for the onset of ice nucleation in each mixed-sample experiment. Significantly, in $100 \%$ of the experiments, the onset of ice formation was observed to occur on ammonium sulfate particles (gray circles, Figure 8). In four of these experiments ice formation occurred on ammonium sulfate particles that also contained an unquantifiably small, yet detectable, amount of glutaric acid. Ice saturation ratios calculated for cases when a detectable amount of glutaric acid was present were not consistently high or low compared to the ice saturation ratios for the other mixedsample experiments. Presumably in these cases the organic material is not present in great enough quantity to cover the ammonium sulfate active sites for nucleation. This suggests that organic species present in small amounts may not affect the ice nucleation properties of certain aerosol particles. Further investigation is required to determine the threshold amount of organic material or coating thickness that may be required to alter the ice nucleation efficiency of ammonium sulfate particles.

It is possible that surface morphology differences between the ammonium sulfate particles and glutaric acid particles (as evident in Fig. 7) may explain, in part, why ammonium sulfate is a more efficient IN than glutaric acid. Using this experimental technique we are not able to precisely quantify how small surfaces defects may influence our results. However, work by Zuberi et al. (2001) suggests that heterogeneous freezing temperatures in the immersion freezing mode are strongly dependent on surface morphology, specifically surface area and particle microstructure. Optical images of the solid ammonium sulfate particles used in the

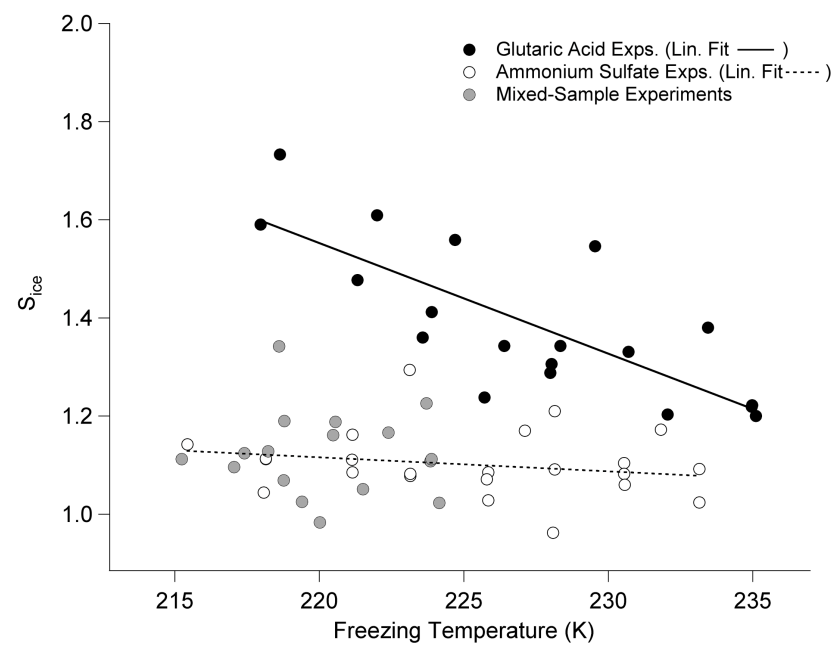

Fig. 8. Presents a summary of ice saturation ratios as a function of freezing temperature for all depositional ice nucleation experiments performed in this study. Black dots correspond to measurements taken during experiments on glutaric acid particles. Open circles represent ice nucleation experiments on solid ammonium sulfate particles. Gray circles show ice saturation ratios observed during mixed-sample experiments. In all mixed-sample experiments the onset of freezing was observed to occur on ammonium sulfate particles.

present work show rough surfaces that may be consistent with the ammonium sulfate microcrystals observed by $\mathrm{Zu}-$ beri et al. (2001) when they found low ice saturation ratios.

\subsection{Comparison of results}

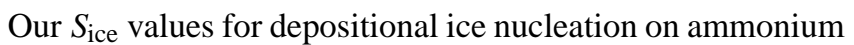
sulfate are in agreement with other literature points available. In a cloud chamber study of ammonium sulfate, Mangold et al. (2005) observed onset $S_{\text {ice values between } 1.20 \text { and } 1.27}$ during several homogeneous ice nucleation experiments. In this case FTIR spectroscopy indicated that a majority of the particles were liquid in phase. However, the authors suggest the presence of some effloresced ammonium sulfate particles may have resulted in lower $S_{\text {ice }}$ values than expected. In a follow-up experiment using crystalline ammonium sulfate, ice formation on ammonium sulfate particles was detected at ice saturation ratios slightly above 1 . Abbatt et al. (2006) used a cloud chamber to depositionally nucleate ice onto solid ammonium sulfate particles. They observed ice formation at ice saturation ratios between 1.14 and 1.22 at $223 \mathrm{~K}$. Abbatt et al. (2006) also observed efficient ice nucleation on solid ammonium sulfate particles for experiments performed on a hydrophobic support. Abbatt et al. (2006) used these studies to explain disparity in previous results for homogeneous ice nucleation of ammonium sulfate particles from IR flow tubes by suggesting that some results were influenced by heterogeneous nucleation on a subset of effloresced ammonium sulfate particles. Shilling et al. (2006) found that 
solid ammonium sulfate and maleic acid particles deposited on a gold plate efficiently nucleated ice at $S_{\text {ice }}$ values between 1.04 and 1.42 over a temperatures ranging from $190 \mathrm{~K}$ to $240 \mathrm{~K}$. Our results are in good agreement with Shilling et al. (2006) in the overlapping temperature range. Eastwood et al. (2009) report an $S_{\text {ice }}$ value of 1.06 observed at $236 \mathrm{~K}$ for depositional ice nucleation on kaolinite particles with a thick coating of ammonium sulfate. Given these conditions, the ammonium sulfate coating is presumably solid, and our observations correspond well with the results of their study.

Glutaric acid results imply that particles with a high concentration of organic species may inhibit depositional ice formation. This observation is consistent with field measurements made by Cziczo et al. (2004) who used mass spectrometry to infer that particles with high organic content were less efficient ice nuclei than sulfates. Similarly, Parsons et al. (2004) found that dicarboxylic acids were inefficient ice nuclei. Our results are in agreement with Kanji et al. (2008) who conclude that although a wide range of materials can act as heterogeneous ice nuclei, hydrophobic surfaces will require higher supersaturations for nucleation to occur depositionally. Another study by Möhler et al. (2008) finds that SOA coatings lowered the high nucleation efficiency of Arizona Test Dust.

In several mixed-sample ice nucleation experiments, the IN particle investigated consisted of an ammonium sulfate core that also contained a small amount of glutaric acid. In these cases, the ice nucleation efficiency of the ammonium sulfate particles was not altered. These results suggest that inhibition of ice nucleation by organic species may occur only when organic coatings are thick enough to cover the active nucleation sites of the core particle. Cziczo et al. (2009) observed a similar effect when investigating the ice nucleation properties of Arizona Test Dust with sulfuric acid and ammonium sulfate coatings using the AIDA chamber. Analysis of single particle ice residues by Cziczo et al. (2009) suggested that the first particles to freeze were those that had thin or incomplete coatings.

In all three types of experiments we observed ice nucleation occurring preferentially on just a few particles per sample. The geometric size of the ice nucleating particles ranged from $0.4 \mu \mathrm{m}$ to $10 \mu \mathrm{m}$, essentially spanning the entire size range of particles on our samples. Thus a size dependence of ice nucleation was not observed for this narrow particle size range. Further, average ice nucleus diameters measured for ammonium sulfate, glutaric acid, and mixed-sample experiments were not significantly different. It is also interesting to note that when a sample was used for multiple experiments ice nucleation was never observed to occur on the same particle twice.

While our results show that chemical composition can influence ice nucleation, at this time it is not clear what is special about the nucleating particles when they all have the same nominal composition. It is possible that microscopic surface features make some particles better ice nuclei than others. For example, Pruppacher and Klett (1997) suggest that active sites may catalyze ice formation through an inverse Kelvin effect. Because the number of active sites does not necessarily scale with particle surface area (Kärcher and Lohmann, 2003), nucleation may not always occur on the largest particles first.

\section{Atmospheric implications}

This work indirectly implies that the deliquescence RH (DRH) may be a useful way to predict whether a substance will form ice via homogeneous or heterogeneous nucleation pathways. Materials with a low DRH (ex. perchlorate, $\mathrm{DRH}=45 \%$ ) will deliquesce before supersaturations required for heterogeneous ice nucleation are reached (Gough et al., 2010). Instead, this type of compound will deliquesce at low RH and then freeze homogeneously. Alternatively, compounds with high DRH values, like ammonium sulfate, may be more likely to nucleate ice heterogeneously at cold temperatures because high supersaturations with respect to ice can be achieved before their DRH is reached. In this case, heterogeneously nucleated ice grows quickly, and may monopolize local water vapor. Thus, homogeneous nucleation may be shut down or occur at higher RH values than otherwise expected. Further experimentation is necessary in order to substantiate this hypothesis.

Our results suggest the onset of heterogeneous nucleation may occur preferentially on ammonium sulfate over homogeneous nucleation at low temperatures in the atmosphere. This pathway for ice formation on ammonium sulfate may be particularly significant in the tropical tropopause region where concentrations of aerosol generally considered to be efficient ice nuclei, such as mineral dust, are low and sulfates make up a large portion of the aerosol available for nucleation (Froyd et al., 2009; Froyd et al., 2010). Recent aircraft measurements have detected large ice crystals $(\sim 100 \mu \mathrm{m})$ present in cirrus clouds near the tropical tropopause. Simulations run by Jensen et al. (2008) suggest that these large ice particles may result from heterogeneous nucleation at low supersaturations. They hypothesize that a few efficient heterogeneous ice nuclei grow to large sizes prior to the onset of homogeneous nucleation. Further work by Jensen et al. (2010) suggests that solid ammonium sulfate particles may be available for ice nucleation in this region. Our results for ammonium sulfate support this mechanism for ice formation in the tropical tropopause region.

Particles in the tropical tropopause layer are also exposed to cold temperatures and have long residence times, which allows for the accumulation of organic matter on particles. PALMS measurements in the tropical tropopause layer suggest that the vast majority of sulfates particles also contain organic species (Froyd et al., 2009). Additional PALMS studies at lower altitudes suggest that aerosol particles with high concentrations of organic species require 
higher supersaturations in order to nucleate ice (Cziczo et al., 2004; DeMott et al., 2003a). Similarly, we observed heterogeneous ice nucleation on glutaric acid at higher values of $S_{\text {ice }}$ than for pure ammonium sulfate. Further, when solid ammonium sulfate and glutaric acid particles are present in the same sample, we observed initial ice formation occurring on ammonium sulfate particles with little or no organic signature at ice saturation levels similar to those observed when only pure ammonium sulfate is present. Continued investigation is necessary to determine the amount of organic that is necessary to inhibit ice formation. Presumably, enough organic material would be needed to cover the active nucleation sites of the core particle. Current work is underway to extend this technique to investigate complex heterogeneous aerosol particles and calculate nucleation rates.

Acknowledgements. The authors gratefully acknowledge the National Science Foundation for supporting this work (NSF-ATM 0650023). K. Baustian received additional support from NASA (NESSF fellowship NNX08AU77H) and by CIRES at the University of Colorado at Boulder.

Edited by: T. Koop

\section{References}

Abbatt, J. P. D., Benz, S., Cziczo, D. J., Kanji, Z., Lohmann, U., and Mohler, O.: Solid ammonium sulfate aerosols as ice nuclei: A pathway for cirrus cloud formation, Science, 313, 1770-1773, 2006.

Archuleta, C. M., DeMott, P. J., and Kreidenweis, S. M.: Ice nucleation by surrogates for atmospheric mineral dust and mineral dust/sulfate particles at cirrus temperatures, Atmos. Chem. Phys., 5, 2617-2634, 2005,

http://www.atmos-chem-phys.net/5/2617/2005/.

Buajarern, J., Mitchem L., and Reid, J. P.: Charactering the formation of organic layers on the surface of inorganic aerosols by raman spectroscopy, J. Phys. Chem. A, 111, 11852-11859, 2007.

Buck, A. L.: New equations for computing vapor pressure and enhancement factor, J. Appl. Meteorol., 20, 1527-1532, 1981.

Cantrell, W. and Heymsfield, A.: Production of ice in tropospheric clouds: a review, B. Am. Meteor. Soc., 6, 795-807, 2005.

Chan, M. N., Lee, A. K. Y., and Chan, C. K.: Responses of ammonium sulfate particles coated with glutaric acid to cyclic changes in relative humidity: hygroscopicity and raman characterization, Environ. Sci. Technol., 40, 6983-6989, 2006.

Cziczo, D. J., Froyd, D. K., Gallavardin, S. J., Moehler, O., Benz, S., Saathoff, H., Murphy, D. M.: Deactivation of ice nuclei due to atmospherically relevant surface coatings, Environ. Res. Lett., 4, 044013, doi:10.1088/1748-9326/4/4/044013, 2009.

Cziczo, D. J., DeMott, P. J., Brooks, S. D., Prenni, A. J., Thomson, D. S., Baumgardner, D., Wilson, J. C., Kreidenweis, S. M. and Murphy, D. M.: Observations of organic species and atmospheric ice formation, Geophys. Res. Lett., 31, L12116, doi:10.1029/2004GL019822, 2004.

DeMott, P. J., Cziczo, D. J., Prenni, A. J., Murphy, D. M., Kreidenweis, S. M., Thomson, D. S., Borys, R., and Rogers, D. C.: Measurements of the concentration and composition of nuclei for cirrus formation, P. Natl. Acad. Sci. USA, 100(25), 1465514660, 2003a.

DeMott, P. J., Sassen, K., Poellot, M. R., Baumgardner, D., Rogers, D. C., Brooks, S. D., Prenni, A. J., and Kreidenweis, S. M.: African dust aerosols as atmospheric ice nuclei, Geophys. Res. Lett., 30(14), 1732, doi:10.1029/2003GL017410, 2003b.

DeMott, P. J., Rogers, D. C., Kreidenweis, S. M., Chen, Y., Twohy, C. H., Baumgardner, D., Heymsfield, A. J., and Chan, K. R.: The role of heterogeneous freezing nucleation in upper tropospheric clouds: Inferences from SUCCESS, Geophys. Res. Lett., 25, 1387-1390, 1998.

Eastwood, M. L., Cremel, S., Wheeler, M., Murray, B. J., Girard, E., and Bertram, A. K.: Effects of sulfuric acid and ammonium sulfate coatings on the ice nucleation properties of kaolinite particles, Geophys. Res. Lett., 36, L02811, doi:10.1029/2008GL035997, 2009.

Froyd, K. D., Murphy, D. M., Sanford, T. J., Thomson, D. S., Wilson, J. C., Pfister, L., and Lait, L.: Aerosol composition of the tropical upper troposphere, Atmos. Chem. Phys., 9, 4363-4385, 2009, http://www.atmos-chem-phys.net/9/4363/2009/.

Froyd, K. D., Murphy, D. M., Lawson, P., Baumgardner, D., and Herman, R. L.: Aerosols that form subvisible cirrus at the tropical tropopause, Atmos. Chem. Phys., 10, 209-218, 2010, http://www.atmos-chem-phys.net/10/209/2010/.

Gettelman, A., Randel, W. J., Wu, F., and Massie, S. T.: Transport of water vapor in the tropical tropopause layer, Geophys. Res. Lett., 29(9), 1-4, 2002.

Hung, H., Malinowski, A., and Martin, S. T.: Ice nucleation kinetics of aerosols containing aqueous and solid ammonium sulfate particles, J. Phys. Chem. A, 106, 293-306, 2002.

Gough, R. V., Baustian, K. J., Wise, M. E., and Tolbert, M. A.: Laboratory investigation of the deliquescence and efflorescence relative humidity of perchlorate salts: implications for mars, in preparation, 2010.

IPCC, 2007: Climate Change 2007: The Physical Science Basis. Contribution of Working Group I to the Fourth Assessment Report of the Intergovernmental Panel on Climate Change, edited by: Solomon, S., Qin, D., Manning, M., Chen, Z., Marquis, M., Averyt, K. B., Tignor, M., and Miller, H. L., Cambridge University Press, Cambridge, UK and New York, NY, USA, 996 pp., 2007.

Jensen, E. J., Pfister, L., Bui, T. V., Lawson, P., Baker, B., Mo, Q., Baumgardner, D., Weinstock, E. M., Smith, J. B., Moyer, E. J., Hanisco, T. F., Sayres, D. S., St. Clair, J. M., Alexander, M. J., Toon, O. B., and Smith, J. A.: Formation of large $(\sim 100 \mu \mathrm{m})$ ice crystals near the tropical tropopause, Atmos. Chem. Phys., 8, 1621-1633, 2008, http://www.atmos-chem-phys.net/8/1621/2008/.

Jensen, E. J., Pfister, L., Bui, T.-P., Lawson, P., and Baumgardner, D.: Ice nucleation and cloud microphysical properties in tropical tropopause layer cirrus, Atmos. Chem. Phys. Discuss., 10, 1369-1384, 2010, http://www.atmos-chem-phys-discuss.net/10/1369/2010/.

Jensen, E. J., Toon, O. B., Pfister, L., and Selkirk, H. B.: Dehydration of the upper troposphere and lower stratosphere by subvisible cirrus clouds near the tropical tropopause, Geophys. Res. Lett., 23(8), 825-828, 1996.

Kanji, Z. A., Florea, O., and Abbatt, J. P. D.: Ice formation via deposition nucleation on mineral dust and organics: dependence of 
onset relative humidity on total particulate surface area, Environ. Res. Lett., 3, 025004, doi:10.1088/1748-9326/3/2/025004, 2008.

Kanji, Z. A. and Abbatt, J. P. D.: Laboratory studies of ice formation via deposition mode nucleation onto mineral dust and n-hexane soot samples, J. Geophys. Res., 111, D16204, doi:10.1029/2005JD006766, 2006.

Kärcher, B. and Lohmann, U.: A parameterization of cirrus cloud formation: Heterogeneous freezing, J. Geophys. Res., 108, 4402, doi:10.1029/2002JD003220, 2003.

Knopf, D. A. and Koop, T.: Heterogeneous nucleation of ice on surrogates of mineral dust, J. Geophys. Res., 11, D12202, doi:10.1029/2005JD006894, 2006.

Koop, T., Luo, B. P., Tsias, A., and Peter, T.: Water activity as the determinant for homogeneous ice nucleation in aqueous solutions, Nature, 406, 611-614, 2000.

Koop, T., Ng, H. P., Molina, L. T., and Molina, M. J.: A new optical technique to study aerosol phase transitions: the nucleation of ice from $\mathrm{H}_{2} \mathrm{SO}_{4}$ aerosols, J. Phys. Chem. A, 102, 8924-8931, 1998.

Mangold, A., Wagner, R., Saathoff, H., Schurath, U., Giesemann, C., Ebert, V., Kramer, M., and Möhler, O.: Experimental investigation of ice nucleation by different types of aerosols in the aerosol chamber AIDA: implications to microphysics of cirrus clouds, Meteorol. Z., 14, 485-497, 2005.

Martin, S. T.: Phase transitions of aqueous atmospheric particles, Chem. Rev., 100, 3403-3453, 2000.

Marti, J. and Mauersberger, K.: A survey and new measurements of ice vapor pressure at temperatures between 170 and $250 \mathrm{~K}$, Geophys. Res. Lett., 20, 363-366, 1993.

Möhler, O., Benz, S., Saathoff, H., Schnaiter, M., Wagner, R., Schneider, J., Walter, S., Ebert, V., and Wagner, S.: The effect of organic coating on the heterogeneous ice nucleation efficiency of mineral dust aerosols, Environ. Res. Lett., 3, 025007, 8 pp., 2008.

Möhler, O., Field, P. R., Connolly, P., Benz, S., Saathoff, H., Schnaiter, M., Wagner, R., Cotton, R., Kramer, M., Mangold, A., and Heymsfield, A. J.: Efficiency of the deposition mode ice nucleation on mineral dust particles, Atmos. Chem. Phys., 6, 3007-3021, 2006, http://www.atmos-chem-phys.net/6/3007/2006/.

Möhler, O., Stetzer, O., Schaefers, S., Linke, C., Schnaiter, M., Tiede, R., Saathoff , H., Kramer, M., Mangold, A., Budz, P., Zink, P., Schreiner, J., Mauersberger, K., Haag, W., Karcher, B., and Schurath, U.: Experimental investigation of homogeneous freezing of sulphuric acid particles in the aerosol chamber AIDA, Atmos. Chem. Phys., 3, 211-223, 2003, http://www.atmos-chem-phys.net/3/211/2003/.

Mund, C. and Zellner, R.: Freezing nucleation of levitated single sulfuric acid/ $\mathrm{H}_{2} \mathrm{O}$ micro-droplets. A combined Raman- and Mie spectroscopic study, J. Mole. Struct., 661-662, 491-500, 2003.
Onasch, T. B., Siefert, R. L., Brooks, S. D., Prenni, A. J., Murray, B., Wilson, M. A., and Tolbert, M. A.: Infrared spectroscopic study of the deliquescence and efflorescence of ammonium sulfate aerosol as a function of temperature, J. Geophys. Res., 104(D17), 21, 317-326, 1999.

Parsons, M. T., Mak, J., Lipetz, S. R., and Bertram, A. K.: Deliquescence of malonic, succinic, glutaric, and adipic acid particles, J. Geophys. Res., 109, D06212, doi:10.1029/2003JD004075, 2004.

Pruppacher, H. R. and Klett, J. D.: Microphysics of clouds and precipitation, Kluwer Academic Publishers, Dordrecht, The Netherlands, 954 pp., 1997.

Prenni, A. J., Wise, M. E., Brooks, S. D., and Tolbert, M. A.: Ice nucleation in sulfuric acid and ammonium sulfate particles, J. Geophys. Res., 106(D3), 3037-3044, 2001a.

Prenni, A. J., DeMott, P. J., Kreidenweis, S. M., Sherman, D. E., Russell, L. M., and Ming, Y.: The effects of low molecular weight dicarboxylic acids on cloud formation, J. Phys. Chem. A, 105, 11240-11248, 2001b.

Shilling, J. E., Fortin, T. J., and Tolbert, M. A.: Depositional ice nucleation on crystalline organic and inorganic solids, J. Geophys. Res., 111, D12204, doi:10.1029/2005JF006664, 2006.

Targino, A. C., Krejci, R., Noone, K. J., and Glantz, P.: Single particle analysis of ice crystal residuals observed in orographic wave clouds over Scandinavia during INTACC experiment, Atmos. Chem. Phys., 6, 1977-1990, 2006, http://www.atmos-chem-phys.net/6/1977/2006/.

Torrie, B. H., Lin, C. C., Binbrek, O. S., and Anderson, A.: Raman and infrared studies of the ferroelectric transition in ammonium sulphate, J. Phys. Chem. Solids., 33, 697-709, 1972.

Twohy, C. H. and Poellot, M. R.: Chemical characteristics of ice residual nuclei in anvil cirrus clouds: evidence for homogeneous and heterogeneous ice formation, Atmos. Chem. Phys., 5, 2289 2297, 2005, http://www.atmos-chem-phys.net/5/2289/2005/.

Wallace, J. M. and Hobbs, P. V.: Atmospheric science an introductory survey, 2, Academic Press, San Diego, CA, USA, 505 pp., 2006.

Whalley, E.: A detailed assignment of the O-H stretching bands of ice I, Can. J. Chem., 55, 3429-3441, 1977.

Yeung, M. C., Ling, T. Y., and Chan, C. K.: Effects of the polymorphic transformation of glutaric acid particles on their deliquescence and hygroscopic properties, J. Phys. Chem., 114, 898-903, 2010.

Zuberi, B., Bertram, A. K., Koop, T., Molina, L. T., and Molina, M. J.: Heterogeneous freezing of aqueous particles induced by crystallized $\left(\mathrm{NH}_{4}\right)_{2} \mathrm{SO}_{4}$, ice and letovicite, J. Phys. Chem. A, 105, 6458-6464, 2001. 